\title{
PENDEKATAN PARODI, SIMBOLIK DAN METAFORA PADA KARYA SENI JOGJA INTERNATIONAL
}

\author{
Sari Wulandari \\ Jurusan Desain Komunikasi Visual, Faculty of Humanities, BINUS University \\ Jl. KH. Syahdan No. 9, Kemanggisan-Palmerah, Jakarta barat 11480 \\ swulandari@binus.edu
}

\begin{abstract}
Ngayogyakarta Negari Exhibition 2012 is part of the Festival of Arts 2012 Ngayogyakarta Hadiningrat Negari held in commemoration of the 2.5-century founding of Ngayogyakarta and 100 years of the birth of Sri Sultan Hamengkubuwono IX, followed by 124 artists Yogyakarta, both painting, photography, sculpture, audio visual, and installation as well which displayed the works of Sri Sultan Hamengkubuwono IX and Yogyakarta themed. Jogja International work sculpture by sculpture artist, Dunadi, is one of the few works of sculpture on display in this activity, similar to superhero Spider-Man but wearing blangkon and sarong. In addition to its large size and white color, which makes it interesting sculpture to be observed, studied and discussed is this artwork has conveyed symbolic, metaphoric, and typical parodik messages of Yogyakarta people. This discussion was done through art criticism and aesthetic theory in which the implementation of theories is very broad in the domain art and design. Although the artwork discussed did not pertain directly to the the domain of Visual Communication Design, sensitivity to social issues, creative approach, and beautiful execution Dunadi artist was expected to add experience and insight into the art of the artists and designers in Indonesia.
\end{abstract}

Keywords: design, sculpture, jogja, spider-man

\begin{abstract}
ABSTRAK
Pameran Negari Ngayogyakarta Hadiningrat 2012 merupakan sebagian dari Festival Seni Rupa 2012 Negari Ngayogyakarta Hadiningrat yang diselenggarakan dalam rangka peringatan 2,5 abad berdirinya Ngayogyakarta Hadiningrat dan 100 tahun lahirnya Sri Sultan Hamengkubuwono IX, diikuti oleh 124 seniman besar Yogyakarta baik seni lukis, fotografi, patung, audio visual serta instalasi yang menampilkan karya-karya bertema Sri Sultan Hamengkubuwono IX dan Yogyakarta. Patung Jogja International karya perupa seni patung Dunadi ini adalah satu di antara beberapa karya seni patung yang dipamerkan dalam kegiatan ini, menyerupai tokoh superhero Spider-Man namun mengenakan blangkon dan sarung. Selain karena ukurannya yang besar dan warnanya yang putih, yang membuat patung ini menarik untuk diamati, diteliti dan dibahas adalah karya seni ini memiliki pesan-pesan yang disampaikan secara simbolik, metaforik dan parodik khas masyarakat Yogyakarta. Pembahasan ini dibedah melalui teori kritik seni dan estetika di mana pengimplementasian teoriteori sangat luas di ranah seni dan desain. Meski karya seni yang dibahas tidak bersinggungan secara langsung dengan ranah Desain Komunikasi Visual, kepekaan terhadap isu sosial, pendekatan kreatif, serta eksekusi yang indah karya seniman Dunadi ini diharapkan dapat menambah pengalaman dan wawasan seni para seniman dan desainer di Indonesia.
\end{abstract}

Kata kunci: desain, patung, yogyakarta, spider-man 


\section{PENDAHULUAN}

Dari kejauhan di sebuah sudut ruang pameran Negari Ngayogyakarta Hadiningrat 2012 tampak sosok manusia berukuran besar berwarna putih yang sedang duduk dengan santaimengenakan sarung dan blangkon. Ia terlihat sedang asik menikmati karya-karya seni yang dipamerkan dalam Festival Seni Rupa 2012 Negari Ngayogyakarta Hadiningrat.Festival ini merupakan perhelatan akbar yang diselenggarakan dalam rangka peringatan2,5 abad berdirinya Ngayogyakarta Hadiningrat dan memperingati 100 tahun lahirnya Sri Sultan Hamengkubuwono IX atau yang dikenal dengan HB IX, sebagai bentuk penghargaan atas jasa-jasa beliau yang telah membentuk dan membangun Yogyakarta, mulai dari hal-hal yang menyangkut politik, sosial, dan budaya hingga bergabungnya Negari Ngayogyakarta Hadiningrat ke dalam Negara Kesatuan Republik Indonesia (NKRI). Semangat perjuangan diusung dalam festival ini di mana karya-karya yang dipamerkan menggambarkan kondisi Yogyakarta baik dalam bentuknya yang fisik, mental maupun spiritual, yang tentunya tidak lepas dari aspek politik, social, dan budaya. Perhelatan ini berlangsung pada tanggal 13-27 April 2012 dan di dalam festival ini terdapat beberapa kegiatan di antaranya adalah pameran, seminar, pemutaran film serta peluncuran buku. Harapan dari diselenggarakannya acara ini adalah untuk meningkatkan gairah dalam eksplorasi seni dan budaya, melahirkan banyak kebaharuan baik dalam segi gagasan, bentuk, gaya maupun material sebagai media berekspresi.

Festival dibuka pada tanggal 13 April 2012 tepat sehari setelah peringatan kelahiran HB IX (almarhum) yang ke-100 tahun. Sosok HB IX dikenal sebagai Raja Kesembilan dari Kesultanan Yogyakarta yang telah berdiri sejak 13 Februari 1755, seorang bangsawan keraton Yogyakarta yang ikut berjuang di medan perang dan bergelar sebagai Sri Sultan Hamengkubuwono ke IX. Beliau adalah pemimpin yang visioner dan berani membawa Negari Ngayogyakarta Hadingrat yang telah berdiri dengan mapan selama 190 tahun untuk bergabung dengan NKRI segera setelah Indonesia merdeka. Ketika itu banyak tokoh intelektual dan seniman yang datang ke Yogyakarta. Sementara sebelumnya Yogyakarta telah banyak melahirkan gerakan-gerakan pendidikan seperti Muhammadiyah, Taman Siswa, Boedi Oetomo, dan lain sebagainya. Begitu pula halnya di bidang seni, di mana Yogyakarta banyak memiliki seniman besar dan berbakat seperti S. Sudjojono, Hendra Gunawan, dan Affandi. Kondisi ini sangat mendukung terbentuknya iklim intelektual nan kreatif di masyarakat Yogyakarta. Maka tidaklah mengherankan apabila kita mengenal banyak seniman yang cerdas dan berkarakter berasal dari Yogyakarta.

Dalam kegiatan pameran seni rupa yang bertempat di Jogja National Museum ini, digelar karya-karya seniman besar Yogyakarta.Pameran ini diikuti oleh 124 seniman baik seni lukis, fotografi, patung, audio visual serta instalasi. Seluruh karya yang ditampilkan bertema HB IX dan Yogyakarta.Yang menarik dari karya-karya ini adalah keberanian seniman dalam merespon tema yang diangkat, kreativitas dalam mengeksplorasi konsep, keleluasaan dalam bereksperimentasi pada media, serta keindahan pada eksekusi akhir. Kesuksesan pameran ini tentunya tidak lepas dari keberhasilan pengkurasiantim yang dipimpin oleh Prof. Dr. M. Dwi Marianto, MFA, PhD, seorang perupa senior dan guru besar ISI Yogyakarta. Dengan kurasi yang mengedepankan semangat kebaharuan, baik dalam segi gagasan, bentuk, gaya maupun material sebagai media berekspresi maka pameran yang digelar ini menjadi begitu bergairah dengan banyaknya kejutan karya yang dapat menambah referensi dan pengalaman seni publiknya. Pengunjung pameran dapat menikmati karya-karya yang memenuhi 3 lantai di bangunan utama dengan karya-karya bertema HB IX dan Yogyakarta yang sangat kental, buah karya para seniman maestro dan seniman muda Yogyakarta. Karya-karya yang dipamerkan di sini menampilkan figur HB IX secara utuh baik dari sisi pribadinya yang begitu mencintai rakyatnya, yang tidak segan mengorbankan jiwa dan raga, hingga pandangannya yang begitu cerdas dan bijaksana dalam menyikapi kondisi politik. Tidaklah mengherankan apabila beliau pun sangat dicintai rakyatnya yang nampak melalui apresiasi masyarakat Yogyakarta yang dimunculkan dalam bentuk karya seni di dalam pameran ini. Berada di dalam ruang pameran, sangatlah mudah untuk merasakan 
energi yang terpancar dan kecintaan yang mengalir melalui karya-karya para seniman Yogyakarta ini.Selain menampilkan sosok HB IX para seniman pun merespon situasi dan kondisi kota Yogyakarta yang sarat akan isu politik, sosial dan kemasyarakatan. Yang sangat menarik untuk diamati, dapat dikatakan bahwa hampir seluruh karya dikemas dengan kreativitas dan gurau canda khas Yogyakarta yang sederhana, dengan isu yang dekat dengan keseharian masyarakat Yogyakarta serta cerdas dalam mengolah verbal dan visual.

Karya-karya yang ditampilkan adalah karya yang dibuat pada tahun 2011 dan tahun 2012. Kebanyakan berupa lukisan dengan berbagai bentuk, gaya, teknik serta media yang sangat beragam, seperti kertas, kanvas, kaca, metal, kayu, kain dan lain sebagainya. Teknik yang digunakan pun bermacam-macam seperti sapuan kuas, cetak saring, cukil, digital print dan masih banyak lagi.Dari ukuran karya seni yang dipamerkan pun sangat beragam, mulai dari yang berukuran kecil yang didisplay di atas pedestal sampai yang berukuran besar hingga memenuhi satu ruangan. Selain seni lukis, karya seni patung pun tidak kalah banyak dan menariknya. Seniman patung banyak melakukan eksplorasi dalam segi bentuk, ukuran, material, teknik, pencahayaan serta lokasi karya tersebut akan ditempatkan.

Sosok manusia putih yang diceritakan di awal tadi adalah satu karya seni patung yang berukuran sangat besar dan menarik untuk diamati, yaitu patung Jogja International. Patung putih berbentuk manusia ini berhasil menyedot perhatian pengunjung pameran, terlihat dari banyaknya masyarakat yang memerhatikan patung ini secara saksama dan ingin berfoto bersama.

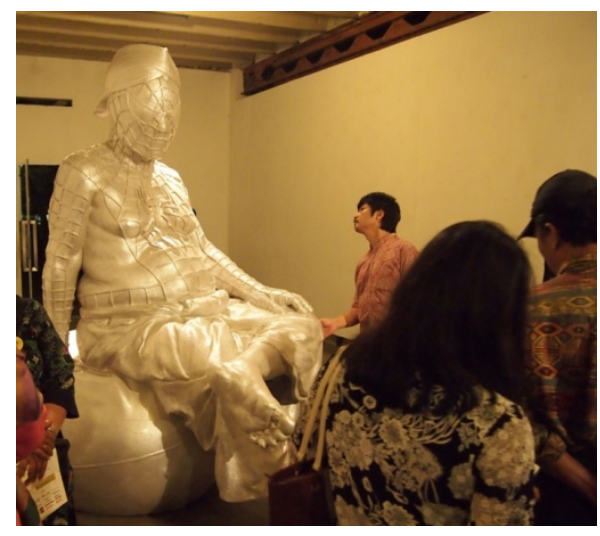

Gambar 1 Karya Seni Patung

Karya patung ekstra besar berwarna putih ini dibuat oleh Dunadi pada tahun 2011, menggunakan media polyester resin dalam berekspresi. Karya ini berbentuk sosok manusia bergender laki-laki berumur sekitar 50 tahun dengan potongan tubuh yang relatif gemuk. Ia sedang duduk santai di atas bangku sofa, dengan menumpangkan kaki kirinya di atas lutut kanan, tangan kanan menopang berat badan yang condong ke belakang, memakai sarung yang dikenakan dengan cara yang seadanya tanpa alas kaki dan tanpa menggunakan baju atasan namun mengenakan blangkon di kepalanya. Ia terlihat sebagai seorang laki-laki Jawa dengan aktivitas sehari-hari yang sedang ote-ote sambil mencari angin (ote-ote dalam bahasa Jawa artinya tanpa mengenakan baju atasan). Yang menjadi menarik disini adalah kenyataan yang terkuak bahwa sosok ini adalah Spider-Man, tokoh kepahlawanan fiksi Amerika keluaran Marvel Comics yang terkenal di banyak belahan dunia.Kenyataan ini teridentifikasi melalui tampilan kulit pada tubuhnya yang bertelanjang dada di mana terdapat alur-alur bergaris jejaring khas laba-laba yang dimiliki oleh tokoh superhero Spider-Man, yang meskipun ditampilkan dengan warna putih (kostum Spiderman selalu ditampilkan dengan warna biru dan merah) namun karakteristik Spider-Man sangat mudah ditangkap. Sungguh merupakan karya yang berkarakter kuat dengan detail yang begitu indah, menggunakan pendekatan parodi (plesetan) yang menjadi ciri khas 
gurauan masyarakat Yogyakarta. Parodi sendiri adalah suatu hasil karya yang digunakan untuk memelesetkan, memberikan komentar atas karya asli, dengan cara yang lucu atau dengan bahasa satir.

\section{METODE PENELITIAN}

Metode yang akan digunakan dalam penelitian ini adalah Metodologi Observasi dengan melakukan pengamatan terhadap objek. Selain itu dilakukan Studi Kepustakaan dengan melakukan riset pustaka baik cetak maupun on-line dengan topik-topikyang berhubungan dengan seni dan desain serta teori-teori Kritik Seni dan Estetika.

\section{HASIL DAN PEMBAHASAN}

Melalui Metodologi Observasi telah dilakukan pengamatan atas seni patung Jogja International yang dipamerkan di kota Yogyakarta. Metode yang digunakan adalah metode dalam Kritik Seni yang mengulas karya dalam empat tahapan yaitu (1) identifikasi dan deskripsi, (2) Analisis, (3) Interpretasi, (4) Evaluasi.Identifikasi dan deskripsi merupakan aktivitas menggambarkan sebuah karya melalui verbal.Kegiatan ini dapat dilakukan melalui serangkaian pengamatan dengan memperhatikan ciri-ciri khusus atas karya sehingga dapat terlihat dengan jelas. Informasi dalam proses deskripsi dapat berupa informasi internal (dari karya itu sendiri) maupun eksternal (di luar karya namun sangat berkaitan). Analisis adalah kegiatan untuk memahami suatu objek secara seksama dengan cara terlebih dahulu melihat setiap komponen yang terdapat pada objek secara mendetil, mengurai objek sampai elemen-elemen yang paling sederhana untuk melihat hubungan antara satu elemen dengan elemen lain, dan relasinya secara keseluruhan.Intepretasi merupakan kegiatan menerangkan, memaparkan atau menafsirkan sesuatu hal.Dapat dilakukan dengan beberapa pendekatan.Upaya intepretasi sesungguhnya merupakan penjembatanan antara karya dengan budaya setempat sehingga dapat dengan mudah dipahami dan diterima oleh masyarakatnya.Penilaian atas suatu karya seni merupakan sebuah kegiatan mempertimbangkan secara seksama suatu karya dengan melihat sisi baik-buruknya untuk memberikan suatu penilaian terhadap kualitas, manfaat, visual atau isi dari sebuah karya.Hal ini tidak terlepas dari bagaimana seorang kritikus memandang karya tersebut. Untuk itu perlu dilakukan studi literatur terlebih dahulu hal-hal yang terkait dengan kota Yogyakarta dan masyarakatnya serta figur karakter komik fiksi Spider-Man yang sudah dikenal di banyak belahan dunia.

\section{Patung Jogja International}

Patung Jogja International yang berbentuk sosok figur manusia direpresentasikan bergaya realis dan proporsional dalam sikap duduk santai, kaki menyilang, satu tangan menopang beratnya tubuh dan tangan lainnya memegang lutut.Secara keseluruhan gestur yang terlihat menyampaikan kesan santai, terbuka, ramah dan nyaman. Dengan ukuran 250 x 192 x $230 \mathrm{~cm}$ yang begitu besar patung ini terlihat sangat menonjol di antara karya-karya seni lainnya. Terlebih dengan warna cat putih metalik yang sangat dominan terlihat menyelimut di seluruh tubuh karya ini. Dengan dukungan pencahayaan yang baik serta unsur warna metalik yang dimilikinya maka detail-detail dari patung ini tampak dengan jelas dan secara keseluruhan tampil sempurna. Patung ini terbuat dari resin dan memiliki tekstur yang halus. Pantulan-pantulan sinar yang umumnya terjadi pada media resin akibat finishing cat yang mengkilap, mengakibatkan detail tidak dapat ditangkap secara lengkap. Namun hal ini tidak terjadi pada karya ini karena finishing dilakukan dengan penambahan unsur metalik sehingga membantu meredam kilap pada permukaan karya. 

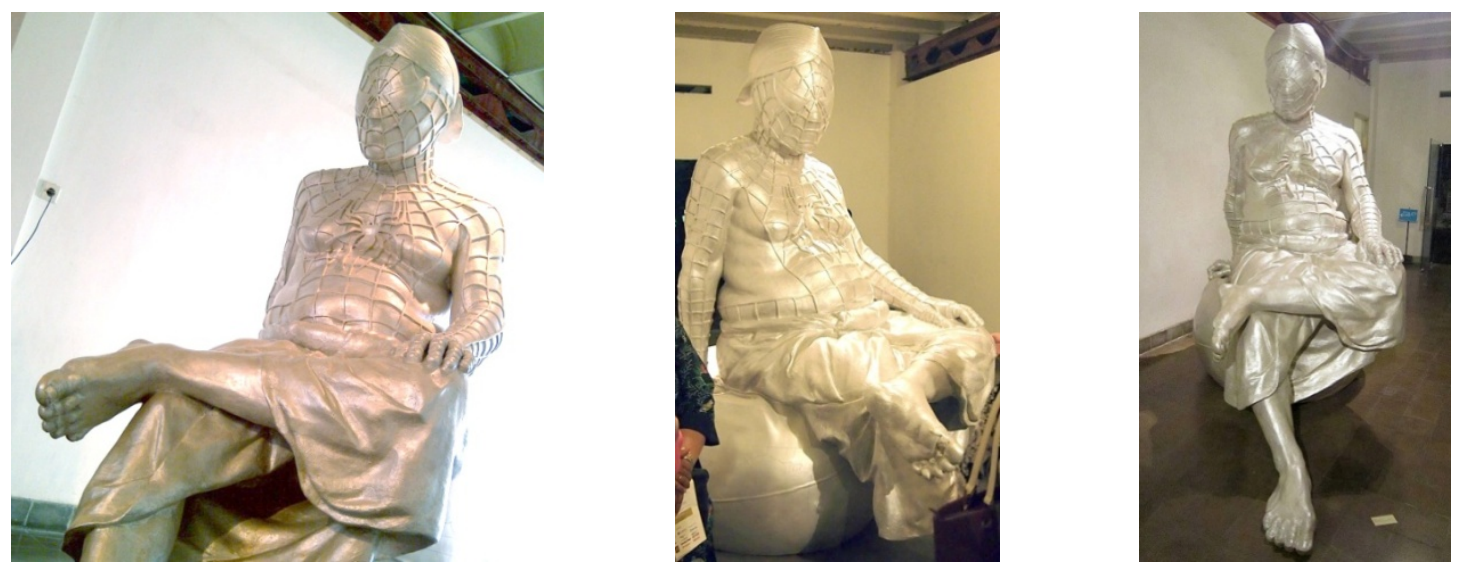

Gambar 2 Patung dalam Jogja International

Dunadi yang lahir di Bantul, Yogyakarta pada tanggal 3 Agustus 1960 dikenal sebagai seorang seniman patung realis yang mampu membuat karya-karya gigantik, secara aktif dan konsisten telah membuat karya patung sejak tahun 1978 dan ia menerima gelar sarjana seni patung dari Institut Seni Indonesia di tahun 1988. Beberapa karyanya dipamerkan di beberapa museum dan monumen seperti Museum Keprajuritan di Taman Mini Indonesia Indah (TMII) Jakarta, Monumen di Muara Enim, Palembang, Monumen Gesang di Solo, dan lain-lain. Ia juga pernah menempuh studi untuk memperdalam keilmuannya di Los Angeles, USA dan menggelar pameran di sana.

\section{Tentang KotaYogyakarta dan Masyarakatnya}

Kota Yogyakarta yang masih kental dengan budayanya, mulai dari nilai-nilai budaya yang dianut, cara berpikir dan perilaku masyarakat hinggakarya seni yang dihasilkan oleh masyarakatnya membuat kota ini istimewa karena memiliki keunikan yang tidak dimiliki oleh kota-kota lainnya di Indonesia. Hal ini pula yang membuat Yogyakarta menjadi satu tujuan wisata baik bagi wisatawan domestik maupun internasional. Bahkan tidak jarang masyarakat internasional khususnya dari dunia barat senang menetap di kota Yogyakarta untuk mempelajari budaya dan kearifan lokal masyarakat Yogyakartakarena saratnya nilai-nilai budaya yang tidak dimiliki oleh masyarakat dunia barat.Masyarakat Yogyakarta yang merupakan bagian dari masyarakat Jawa dikenal dengan ciri khas di mana masyarakatnya sangat menjaga tata kesopanan terutama kepada orang yang lebih tua, atau kepada mereka yang memiliki kedudukan lebih tinggi.Sikap ini melahirkan budaya sungkan sehingga dalam menyampaikan hal yang kurang menyenangkan kepada orang tua atau atasan, tidak disampaikan secara terbuka namun seringkali digunakan pendekatan plesetan yang dikemas dengan segarsehingga pesan tersebut dapat tersampaikan dengan baik tanpa menyinggung perasaan. Cara pendekatan plesetan juga sering digunakan dalam gurauan disela pembicaraan sehari-hari.Selain itu masyarakat Yogyakarta juga memiliki sikap yang unik dalam hal keagamaan, di mana adat kebiasaan tetap dilakukan meskipun anggota masyarakat telah memeluk satu agama.Hal ini disebabkan karena mereka masih menjunjung tinggi tradisi upacara dan ritual. Mereka juga dekat dengan filosofi pewayangan, di mana rata-rata orang Jogja memahami cerita dan menjunjung tinggi nilai-nilai yang terkandung dalam cerita pewayangan, bahkan tidak jarang mereka mengidolakan satu atau beberapa tokoh pewayangan yang dianggap dapat menjadi panutan dalam mengarungi kehidupan. Tidaklah mengherankan ketika pergelaran wayang semalam suntuk selalu dibanjiri oleh penonton dari segala umur dan segala kalangan. Dengan memegang teguh filosofi pewayangan ini masyarakat Yogyakarta berkembang menjadi masyarakat yang berbudi luhur. Dalam berbusana pun merupakan pemandangan yang biasa ditemukan di Jogja di mana seorang pria mengenakan blangkon (penutup kepala), berbaju surjan (baju berbahan lurik) dan sarung, baik dalam kegiatan ritual maupun keseharian. Berikut ini adalah pembahasan lebih lanjut mengenai blankon dan sarung. 


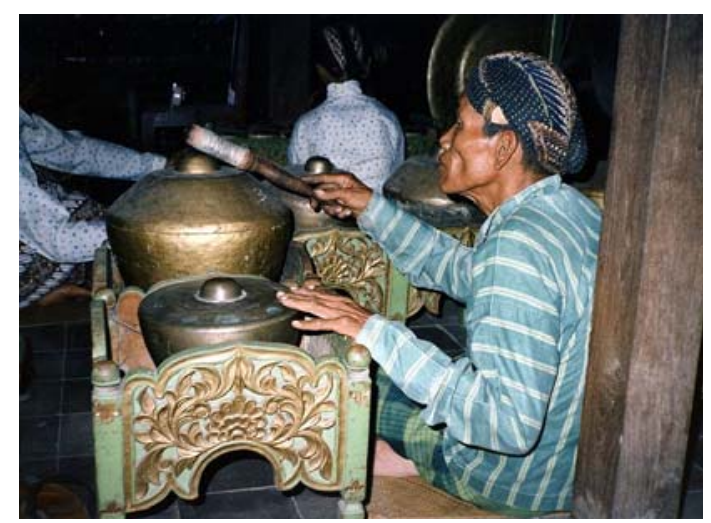

Gambar 3 Seorang dengan Blangkon, Berbaju Surjan, dan Sarung

Blangkon adalah tutup kepala yang digunakan oleh kaum pria sebagai bagian dari pakaian tradisional Jawa.Blangkon sebenarnya merupakan bentuk praktis dari iket yaitu tutup kepala yang dibuat dari batik.Ada sejumlah teori yang menyatakan bahwa pemakaian blangkon merupakan pengaruh dari, budaya Hindu dan Islam yang diserap oleh orang Jawa.Menurut para ahli, orang Islam yang masuk ke Jawa terdiri dari dua etnis yaitu keturunan China dari Daratan Tiongkok dan para pedagang Gujarat.Para pedagang Gujarat ini adalah orang keturunan Arab, mereka selalu mengenakan sorban, yaitu kain panjang dan lebar yang diikatkan di kepala mereka.Sorban inilah yang menginspirasi orang Jawa untuk memakai iket kepala seperti halnya orang keturunan Arab tersebut.Ada teori lain yang berasal dari para sesepuh yang mengatakan bahwa pada jaman dahulu, iket kepala tidaklah permanen seperti sorban yang senantiasa diikatkan pada kepala. Tetapi dengan adanya masa krisis ekonomi akibat perang, kain menjadi satu barang yang sulit didapat.Oleh sebab itu, para petinggi keraton meminta seniman untuk menciptakan ikat kepala yang menggunakan separoh dari biasanya untuk efisiensi.Maka terciptalah bentuk penutup kepala yang permanen dengan kain yang lebih hemat yang disebut blangkon.Pada jaman dahulu, blangkon memang hanya dapat dibuat oleh para seniman ahli dengan pakem (aturan) yang baku. Semakin memenuhi pakem yang ditetapkan, maka blangkon tersebut akan semakin tinggi nilainya. Penilaian mengenai keindahan blangkon, menurut ahli budayawan Becker yang pernah meneliti soal blangkon, selain dari pemenuhan terhadap pakem juga tergantung pada sejauh mana seseorang mengerti akan standar cita rasa serta ketentuanketentuan yang sudah menjadi standar sosial. Pakem yang berlaku untuk blangkon, ternyata bukan hanya harus dipatuhi oleh pembuatnya, tetapi juga oleh para penggunanya.

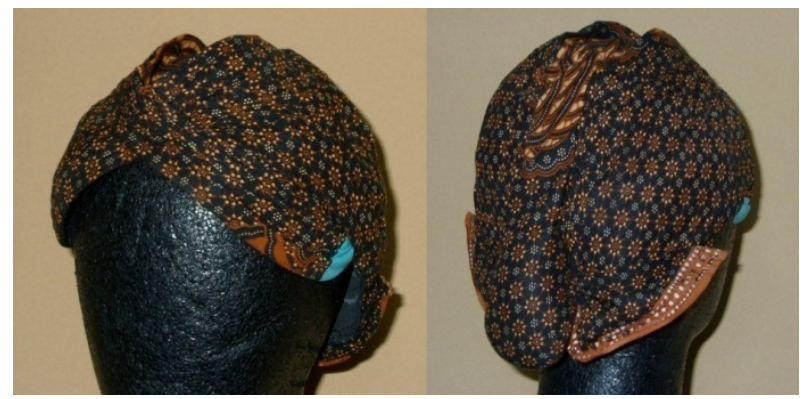

Gambar 4 Blangkon

Blangkon pada prinsipnya terbuat dari kain iket atau udeng berbentuk persegi empat bujur sangkar. Ukurannya kira-kira selebar $105 \mathrm{~cm}$ x $105 \mathrm{~cm}$. Yang dipergunakan sebenarnya hanya separoh kain tersebut.Ukuran blangkon diambil dari jarak antara garis lintang dari telinga kanan dan kiri melalui dahi dan melalui atas. Blangkon terdiri dari beberapa gaya yang tergantung dari asal 
daerahnya. Blangkon khas Jogja menggunakan mondholan, yaitu tonjolan pada bagian belakang blangkon yang berbentuk seperti telur. Blangkon ini disebut sebagai blangkon gayaJogja. Tonjolan ini menandakan model rambut pria masa itu yang sering mengikat rambut panjang mereka di bagian belakang kepala, sehingga bagian tersebut tersembul di bagian belakang blangkon.Lilitan rambut itu harus kencang supaya tidak mudah lepas.

Sarung di Indonesia secara keagamaan sudah diklaim menjadi satu jenis pakaian tradisi Muslim di Indonesia, sebagai pakaian untuk sholat, pergi ke masjid, pergi tahlilan ke tempat saudara maupun teman yang meninggal, dan memperingati hari raya baik Idul Fitri maupun Idul Adha serta aktivitas keagamaan lainnya.Tampaknya ada beberapa faktor yang membuat sarung begitu melekat dalam tradisi Islam di Indonesia, antara lain karena sarung sangat mudah dipakai dan simpel. Selain itu dengan ukurannya yang panjang, longgar dan tebal sehingga mudah menutupi aurat dengan baik serta tidak menunjukkan lekuk tubuh pemakainya. Meskipun umumnya banyak dikenakan di kalangan santri pondok pesantren saja, seluruh lapisan masyarakat juga sudah familiar dan akrab dengan sarung. Sarung dipakai berbagai kalangan baik anak-anak, remaja, maupun orang tua tidak mengenal ras maupun golongan, baik kaya maupun miskin. Sarung banyak digunakan untuk bersantai di rumah serta melindungi diri dari udara yang dingin.

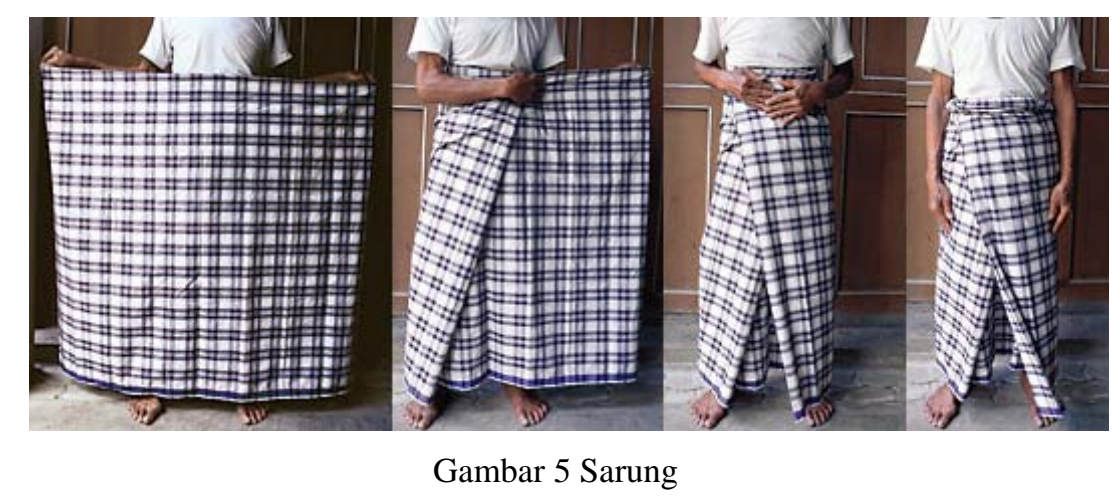

\section{Tentang Spider-Man}

Spider-Man adalah tokoh superhero fiktif yang diciptakan oleh Stan Lee dan Steve Ditko dalam bentuk buku komik yang diterbitkan oleh Marvel Comics pada tahun 1962 ini untuk pertama kalinya pada tahun 2002 karakter Spiderman ini diangkat ke layar lebar dan mendapat sambutan luar biasa dari masyarakat di seluruh dunia, hingga dibuat sekuelnya Spider-man 2 (tahun 2004) dan Spider-man 3 (2007) dan seluruhnya masuk ke dalam kategori blockbuster (film yang sangat populer atau sangat sukses pemasarannya). Spider-Man menjadi satu dari beberapa karakater fiksi superhero yang paling dikenal oleh masyarakat di seluruh dunia, yang kemudian hadir dalam bentuk boneka, permainan, makanan ringan, peralatan sekolah dan masih banyak lagi.
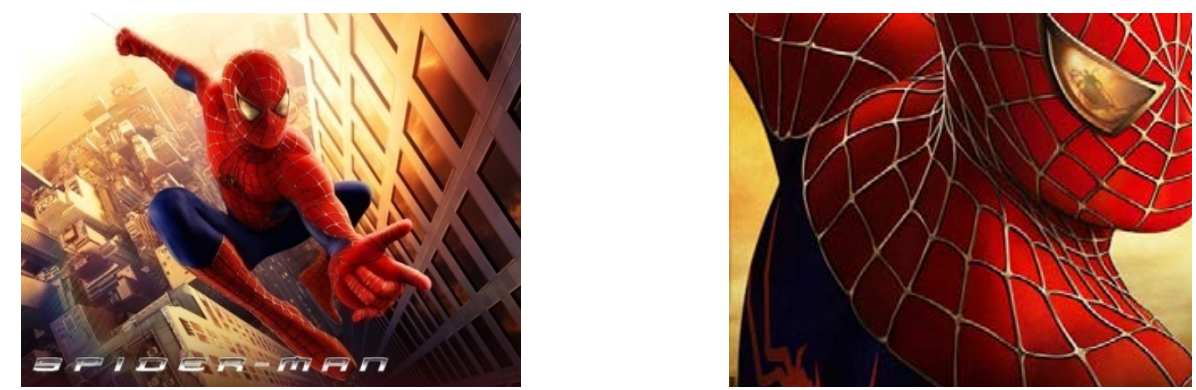

Gambar 6 Spider-Man 
Pada awal cerita dikenalnya Spider-Man, ia adalah siswa SMU yang tampak sangat terpelajar dan kutu-buku serta sulit untuk menjalin hubungan dengan wanita. Karena orangtuanya telah tiada maka ia tinggal dengan kakek dan neneknya. Pada suatu malam ia menemukan bahwa kakeknya meninggal akibat korban perampokan. Ia begitu terpukul dan menyesal mengingat di pagi harinya ia bertengkar dengan sang kakek dan belum sempat berdamai hingga ajal menjemput sang kakek. Pada suatu hari di saat melakukan kunjungan ke sebuah museum serangga bersama teman-teman sekolahnya, ia digigit oleh satu spesies laba-laba jenis langka dan efek kimiawi dari racun laba-laba telah mengganggu sistem biologi tubuhnya. Dalam satu malam ia memiliki kemampuan yang menyerupai laba-laba yaitu mampu mengeluarkan jaring, merayap di tembok dan melompat dari satu tempat ke tempat lain dengan cara bergelayut. Dengan kemampuannya ituia bertekad untuk membela kaum yang lemah, yang tertindas, sebagaimana kejadian yang pernah menimpa kakek yang begitu ia sayangi. Saat melancarkan aksi kepahlawanannya iamenggunakan kostum berwarna merah dan biru khas bendera Amerika dengan visual figur laba-laba serta jaringnya. Dalam kostum itu ia terlihat berpostur tegap, atletis, memiliki sikap yang santun, selalu siap siaga dan menjadi pahlawan masyarakat ketika kondisi mengancam keamanan warga kota.

\section{Jogja International sebagai Ekspresi Kota Yogyakarta Masa Depan}

Sebuah benda seni tentunya tidak terlepas dari ekspresi senimannya, di mana benda seni yang diciptakannya memiliki nilai-nilai tertentu yang ingin disampaikan kepada publik. Dalam penyampaian nilai-nilai ini tentunya dilakukan dengan cara yang tepat dan menyenangkan sehingga publik dapat menangkap pesan yang ingin disampaikan oleh sang seniman. Hal ini tentunya tidak dapat dilepaskan dari konteks budaya yang melingkupi benak publik serta pengalaman seni yang dimiliki oleh publik.

Dalam karya Jogja International ini, secara unik Dunadi yang selalu sensitif dan peka terhadap isu sosial tampaknya ingin menyampaikan penghargaan atas kondisi kota Jogja yang nyaman, sarat dengan unsur nilai-nilai lokal yang terpelihara, memiliki nilai budaya yang tinggi serta tradisi yang kuat. Hal-hal inilah yang membuatsosok Spider-Man yang merupakan pahlawan masyarakat di Amerikamemilih Yogyakarta sebagai kota yang nyaman untuk bersantai bahkan untuk menghabiskan masa tuanya, di mana terlihat bahwa ia sangat santai dengan mengenakan pakaian yang seadanya. Tampak dari gestur tubuhnya yang cenderung menyender ke belakang dengan bertumpu pada tangan kanannya, sedangkan kaki kanan disilangkan di atas lutut kirinya, memakai sarung yang dikenakan secara seadanya, tanpa penutup tubuh bagian atas, serta tidak lupa mengenakan blangkon Jogja yang merupakan satu-satunya atribut kunci yang dapat memperlihatkan identitas dan menyatakan bahwa sosok ini adalah seorang laki-laki Jogja. Melalui ukuran patung yang ekstra besar menunjukkan kebesaran serta kehebatan sosok tokoh superhero Spider-Man yang dikenal bertubuh atletis, sikap yang sigap dengan tindak tanduknya yang sopan dan formal, serta cenderung memiliki penampilan yang sempurna dalam membela kaum yang lemah. Hal yang tidak umum terlihat dari patung ini adalah Spider-Man yang ditampilkan dalam kondisi fisik yangberbeda bahkan cenderung bertolak belakang.Dengan tubuhnya yang gemuk dan menampilkan gelambir di sekitar perutnya menjadi penandakerangka waktu di masa depan, bahwa inilah kondisi Spider-Man yang setelah selama puluhan tahun selalu bekerja keras membela kebenaran.Saat pensiun dari kegiatannyaiasenang menikmati hari tuanya di kota Yogyakarta. Yogyakarta adalah kota yang nyaman untuk ditinggali selain karena masih memiliki nilai-nilai luhur, juga merupakan kota yang universal di mana masyarakat Yogyakarta sudah terbiasa berinteraksi dengan masyarakat internasional.Itulah sebabnya mengapa patung seluruhnya dicat dengan warna putih selain untuk menanggalkan identitas Amerika (kostum Spider-Man berwarna merah dan biru khas bendera Amerika) juga untuk menunjukkan kemurnian hati dan keluhuran budi seorang superhero.Karya seni ini dapat diterima oleh publik karena sosok Spider-Man dikenal luas di Indonesia dari kota besar hingga pelosok desa, dari orang tua hingga anak-anak.Seperti yang ada di desa Sukodadi, Lamongan tepatnya di desa Sumberaji Dusun Bulakyang banyak membuat topeng mainan anak-anak yang terbuat dari kertas dan karpet, yang dicetak menyerupai bentuk aslinya seperti topeng Ksatria Baja hitam, Spider-Man, dan lain-lain.Selain mereka mengetahui keberadaan daritokoh 
komik Spider-Man, mereka juga memiliki referensikarakter Spider-Man sebagai sosok figur superhero yang membela kaum yang lemah.

\section{Kebaharuan dalam Karya Jogja International}

Karya seni Jogja International ini memiliki keunikan yaitu dengan mengangkat tokoh manusia fiksi yang awalnya dikenal melalui komik dan layar lebar kemudian diubah menjadi tokoh yang 'hidup' di alam nyata. Keunikan lain yang terdapat pada karya seni ini terlihat bahwa dalam proses pembuatannya Dunadi melakukan observasi yang sangat mendalam, di mana ia memilihblangkon dan sarung untuk dikenakan oleh tokoh fiksi superhero Spider-Man yang dikenal oleh masyarakat di seluruh dunia dan dapat mewakili sosok internasional. Aspek ini kemudian diformalkan oleh Dunadi dengan sangat jelas pada judul karya.

Karya Dunadi ini memiliki kebaharuan baik dalam segi gagasan yaitu menyampaikan pesan yang positif atas kondisi kota Yogyakarta di masa depan, maupun dalam segi artifakdan pendekatan gaya parodi melalui metafora yang menggabungkan tokoh Spider-Man dengan sosok seorang laki-laki Jogja.Sungguh merupakan karya yang berkarakter kuat dengan detail yang begitu indah, menggunakan pendekatan parodi (plesetan) yang menjadi ciri khas gurauan masyarakat Yogyakarta.Parodi sendiri adalah suatu hasil karya yang digunakan untuk memelesetkan, memberikan komentar atas karya asli, dengan cara yang lucu atau dengan bahasa satire.Pendekatan parodi ini dinilai tepat untuk menyampaikan pesan secara segar dan kreatif khas Jogja, dari orang Jogja kepada orang Jogja dalam konteks budaya Jogja sehingga karya seni terlihat 'sangat Jogja' namun dapat pula menjadi 'sangat universal' baik dalam bentuk fisik, mental dan spiritual yang terkandung di dalamnya. Hal ini dapat terwujud melalui penggunaan sarung dan blangkon mendhol khas Jogja dan secara simbolik dikenal masyarakat secara luas, pemilihan Spider-Man sebagai tokoh superhero yang dimetaforakan, gestur yang ditampilkan serta pendekatan parodi khas Jogja dalam berkomunikasi. Melalui metafora ini memungkinkan akan ditemukannya sosok superhero lain yang juga tinggal di kota Yogyakarta. Tidaklah mengherankan apabila pada suatu saat kita bertemu dengan Wonder Woman sedang berbelanja di Pasar Bringharjo tidak dalam kostum ketatnya melainkan dengan busana kebaya dan kain batik, atau bertemu dengan Captain America yang sedang menikmati angkringan sego kucing dengan mengenakan surjan berlurik.

\section{SIMPULAN}

Sebagaimana layaknya sebuah benda seni, patung Jogja International ini tentunya memiliki fungsi seni sebagai alat penyampai pesan. Sebagai sebuah benda seni, ia merupakan perwujudan buah ekspresi dan imajinasi seorang seniman patung, Dunadi, yang ingin menggambarkan kota Yogyakarta yang nyaman pada masa depan dengan nilai-nilai budaya yang terus dimiliki masyarakat kota Yogyakarta. Dengan pendekatan parodi, simbolik, dan metafora yang dilakukan oleh Dunadi, serta memerhatikan konteks budaya dan referensi visual (seni) yang dimiliki publik, pesan yang ingin disampaikan melalui karya ini dapat diterima publik dengan baik secara nyaman dan menyenangkan. 


\section{DAFTAR PUSTAKA}

(2012). Festival Seni Rupa 2012 Negari Ngayogyakarta Hadiningrat. $\quad$ Yogyakarta: $\quad$ Jogja National Museum.

Artha, A. T. (2000). Yogyakarta Tempo Doeloe Sepanjang Catatan Pariwisata. Yogyakarta: BIGRAF.

Hardjowirogo, M. (1989). Manusia Jawa. Jakarta: Haji Masagung.

http://en.gtwallpaper.com/fondecran/spiderman/spiderman_45.jpg

http://en.wikipedia.org/wiki/File:Gamelan-Yogyakarta.jpg

http://kerajinannusantara.com/en/news/r/2011/03/04/History-Blangkon

http://sarung.net/artikel/sejarah-sarung/

http://trailers.apple.com/trailers/sony_pictures/spider-man_2/trailer/

http://www.jakartabiennale.org/id/game-leisure-and-gadget-victim/dunadi

http://www.k5.dion.ne.jp/ museum/headdress/blangkon.htm

Koentjaraningrat. (2009). Pengantar Ilmu Antropologi. Jakarta: Rineka Cipta.

Marianto, M. D. (2011). Menempa Quanta Mengurai Seni. Yogyakarta: ISI Yogyakarta.

Soemardjo, J. (2000). Filsafat Seni. Bandung: ITB. 